\title{
PENERAPAN READING GUIDE DALAM PEMBELAJARAN DI MADRASAH
}

Penerapan Reading Guide Dalam...

\author{
Oleh: Moh. Sutomo \\ (Dosen FTIK IAIN Jember) \\ Email: sutomompd@yahoo.com
}

\begin{abstract}
Learning about religious education still uses many conventional methods, where this method requires students to agree with what the teacher has said. The teacher does not familiarize students to be more active than teachers, even though in the present era the demands of the times really need output that is reliable in all things. Problems that are often encountered in lessons, especially Islamic teaching is how to present material to students well and efficiently. Keywords: Application, Reading Guide, Learning
\end{abstract}

\begin{abstract}
Abstrak
Pembelajaran pendidikan Agama masih banyak menggunakan metode konvensional, dimana metode ini menuntut peserta didik untuk mengiyakan apa yang telah dikatakan oleh guru. Guru tidak membiasakan peserta didik untuk menjadi lebih aktif dari pada guru, padahal pada era sekarang ini tuntutan zaman sangat membutuhkan output yang handal dalam segala hal. Permasalahan yang seringkali dijumpai dalam pelajaran, khususnya pengajaran agama Islam adalah bagaimana cara menyajikan materi kepada siswa secara baik dan efesien.
\end{abstract}

Kata Kunci: Penerapan, Reading Guide, Pembelajaran

\section{PENDAHULUAN}

Suatu hal yang tidak dapat dipungkiri bahwa kehidupan dan peradaban manusia di awal milenium ketiga ini mengalami banyak perubahan. Dalam merespon fenomena ini, manusia berpacu mengembangkan pendidikan dalam semua lapangan ilmu pengetahuan (sosial, alam, pasti dan ilmu terapan). Seiring perkembangan tersebut, muncul sejumlah krisis multidimensi dalam kehidupan berbangsa dan bernegara, baik bidang idiologi, politik, ekonomi, sosial, budaya, pertahanan maupun keamanan. Konsekwensinya, peran serta efektivitas pendidikan agama di sekolah sebagai pemberi nilai spiritual terhadap kesejahteraan masyarakat dipertanyakan. Dengan asumsi bahwa jika pendidikan agama dilaksanakan dengan baik, maka kehidupan masyarakat pun akan lebih baik.

Agar kondisi ini bisa terwujud maka diperlukan sistim yang baik pula. Karenanya, Pemerintah membuat aturan strategis berupa Undang-Undang Republik Indonesia Nomer 20 tahun 2003 tentang Sistem Pendidikan Nasional, dengan harapan keadaan masyarakat lebih baik dan kondusif untuk menjawab tantangan zaman. Sebagaimana termaktub dalam bab II Pasal 3 bahwa:

134 | Jurnal Auladuna 


\section{Moh. Sutomo}

"Pendidikan nasional berfungsi mengembangkan kemampuan dan membentuk watak serta peradaban bangsa yang bermartabat dalam rangka mencerdaskan kehidupan bangsa, bertujuan untuk berkembangnya potensi peserta didik agar menjadi manusia yang beriman dan bertaqwa kepada Tuhan Yang Maha Esa, berakhlaq mulia, sehat, berilmu, cakap, kreatif, mandiri, dan menjadi warga negara yang demokratis serta tanggung jawab". ${ }^{1}$

Agar supaya pelaksanaan Undang-Undang ini berjalan efektif dan effisien, perlu dilengkapi pedoman operasional berupa Kurikulum Berbasis Kompetensi (Basic Competency) yang lebih menitik beratkan pada pencapaian target kompetensi; lebih mengakomodasikan keragaman kebutuhan dan sumber daya pendidikan yang tersedia; serta memberikan kebebasan yang lebih luas kepada pelaksana pendidikan di lapangan untuk mengembangkan dan melaksanakan program pembelajaran sesuai dengan kebutuhan.

Pembelajaran berbasis kompetensi merupakan pembelajaran yang dirancang untuk menggali potensi dalam pengalaman belajar siswa agar mampu memenuhi pencapaian kompetensi yang telah ditetapkan. ${ }^{2}$ Dalam ajaran Islam, pendidikan agama Islam sebagai wacana yang memiliki tingkat urgenitas yang tinggi terhadap proses pengembangan seutuhnya dan harus menjadi prioritas dalam membangun tatanan yang lebih progresif. Sedangkan menurut Zakiyah Drajat sebagaimana dikutip Majid, dkk bahwa pendidikan Islam adalah suatu usaha untuk membina dan mengasah peserta didik agar senantiasa memahami ajaran Islam secara menyeluruh. ${ }^{3}$

Mengingat pentingnya pendidikan dalam kehidupan manusia dan pentingnya proses pembelajaran untuk mendapatkan ilmu pengetahuan, maka dalam ajaran Islam kedua proses tersebut sangatlah ditekankan pelaksanaannya. Agar supaya proses belajar-mengajar berjalan dengan baik dibutuhkan pendekatan pembelajaran terpadu dan metode pengajaran yang sesuai dengan tujuan, salah satunya adalah "Reading Guide". Reading Guide adalah suatu metode dimana siswa dituntut untuk menjadi lebih aktif memahami materi ajar sesuai dengan tujuan pengajaran dengan cara melaksanakan tugas yang diberikan oleh guru dalam bentuk tulisan. Reading guide ini dilaksanakan bilamana alokasi waktu belajar-mengajar di kelas tidak seimbang dengan alokasi waktu yang tersedia. Dengan metode ini diharapkan siswa lebih aktif mengekplorasi wawasan terhadap materi ajar yang disajikan guru karena siswa akan memiliki

\footnotetext{
${ }^{1}$ Undang-Undang Republik Indonesia No. 20 Tahun 2003, Tentang Sistem Pendidikan Nasional, 2003, Bandung: Citra Umbara, h. 7.

${ }^{2}$ Mulyasa, 2005:94.

3 Abdul Majid \& Andayani, 2005, Pendidikan Agama Islam Berbasis Kompetensi, Bandung: Remaja Rosdakarya, h.130.
} 
dua kegiatan secara simultan yaitu kreatif membaca, membuat pertanyaan dan jawaban; dan tujuan pembelajaran bisa tercapai secara optimal.

Sedangkan dalam A Guide to Resources, Reading Guide dari pada reading guide ialah petunjuk guru. Guru menguraikan konsep sesuai dengan tujuan, kebutuhan dan pengetahuan anak. Kemudian, guru menbulis pertanyaan dan atau pernyataan yang memandu murid untuk membaca dan merespon (menanggapi) konsep dan bahan bacaan /teks). Maksud dari batasan di atas adalah reading guide merupakan penuntun bagi guru dalam menyajikan pelajaran kepada peserta didik dengan mengajukan beberapa pertanyaan untuk memperoleh respon dari mereka dan merangsang mereka mempelajari bahan bacaan yang diberikan. Dengan metode Reading Guide ini maka guru bisa menciptakan suasana kelas lebih aktif, dengan cara memberikan suatu bacaan sehingga peserta didik dapat membuat pertanyaan dan mampu menjawab ataupun membuat sebuah statemen.

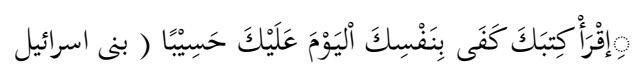

Artinya "bacalah kitabmu, cukuplah dirimu sendiri pada waktu ini sebagai penghisap terhadapmu". ${ }^{4}$

Realita menunjukkan bahwa, masih sedikit jumlah siswa yang memiliki minat baca, sehingga mempengaruhi kualitas wawasan dan ilmu pengetahuannya. Oleh sebab itu tujuan reading guide yaitu agar supaya siswa bisa menumbuhkan keinginan membaca dan mengkritisi suatu bacaan. Sehingga dengan begitu proses pembelajarn menjadi lebih aktif. Materi Agama adalah merupakan satu mata pelajaran yang erat sekali hubungannya dengan kehidupan seharihari siswa, keefektifan pembelajaran Agamasangat di dukung dengan pemahaman siswa tentang ajaran Islam dan kesadaran siswa untuk mengaplikasikannya kedalam kehidupan sehari-hari. Oleh karena itu, dalam metode Reading Guide pada mata pelajaran Agama siswa dapat bertanya dan menjawab apa yang telah siswa ketahui maupun belum diketahui.

\section{PEMBAHASAN}

\section{Konsep tentang Reading Guide}

\section{a. Pengertian Reading guide}

Read dalam kamus Oxford adalah look at and understand, sedangkan reading adalah kata kerja yang berarti act of one who reads. Sedangkan Guide adalah person who shows others way. Jadi maksud dari pada arti Reading guide adalah panduan membaca.

\footnotetext{
${ }^{4}$ Departemen Agama RI, 1989, Al-Qur'an dan Terjemahannya, Semarang, CV. Thoha Putra, h. 426. Jurnal Auladuna | 136
} 


\section{Moh. Sutomo}

Sedangkan dalam $A$ Guide To Resources, ${ }^{5}$ pengertian dari pada reading guide ialah Reading Guide ialah dari pada reading guide ialah petunjuk guru. Guru menguraikan konsep sesuai dengan tujuan, kebutuhan dan pengetahuan anak. Kemudian, guru menulis pertanyaan dan atau pernyataan yang memandu murid untuk membaca dan merespon (menanggapi) konsep dan bahan bacaan /teks).

Maksud dari penjelasan pengertian di atas adalah guru yang berperan aktif untuk menstimulasi peserta didik untuk menjadi lebih aktif dalam proses pembelajaran. Metode Reading guide adalah upaya guru dalam menciptakan suasana kelas menjadi aktif, dengan memberikan suatu bacaan sehingga peserta didik dapat membuat pertanyaan dan mampu menjawab ataupun membuat sebuah statemen.

Sedang menurut Hisyam Zaini; Reading guide (Panduan Membaca) merupakan metode yang membantu pendidik dalam menyelesaikan suatu unit pelajaran tertentu, dimana pelajaran tersebut tidak dapat diselesaikan dikarenakan banyaknya materi. Dan hal ini di gunakan di luar jam pelajaran.

Pencapaian tujuan dalam pendidikan haruslah seorang pendidik mengerti akan adanya peranan penting dalam profesinya. Adapun peranan seorang pendidik untuk menciptakan output yang baik adalah transfer of knowledge (pengetahuan), transfer of value (nilai-nilai), dan transfer of skill (kecakapan). ${ }^{6}$

Untuk menjadikan atau menciptakan output yang handal, maka guru sebagai pendidik diusahakan membimbing peserta didik agar supaya menanamkan minat baca sehingga dapat menambah ilmu pengetahuan serta aktif dalam proses pembelajaran.

Banyak orang menaruh harapan atas terwujudnya kondisi pembelajaran siswa aktif. Agar siswa dapat terlibat aktif dalam proses pembelajaran diperlukan adanya proses pembiasaan. Untuk itu, perlu diidentifikasikan beberapa kecakapan dasar penunjang yang harus menjadi kemampuan yang melekat dalam diri siswa. Beberapa kemampuan dasar tersebut antara lain :

a. Kemampuan bertanya.

Kemampuan ini tidak lain adalah kemampuan siswa untuk mempersoalkan ( problem posing ). Dimulai dengan persoalan dalam wujud pertanyaan, maka dalam diri siswa terdapat keinginan untuk mengetahui dalam proses belajarnya;

\footnotetext{
${ }^{5}$ Edisi 2006:1

${ }^{6}$ Departemen Agama RI, 2003, Standar Penilaian di Kelas, Jakarta. h.2
} 
b. Kemampuan pemecahan masalah (problem solving).

Permasalahan yang muncul didalam pembelajaran harus diselesaikan (dicarikan jawabannya) oleh siswa selam belajarnya. Tidak cukup kalau siswa mahir dalam mempersoalkan sesuatu tetapi miskin dalam mencari pemecahannya. Penyelesaian masalah sendiri dapat dilakukan secara mandiri (self independence learning) maupun kelompok (group learning).

c. Kemampuan berkomunikasi.

Dalam konteks pemahaman, kemampuan berkomunikasi baik verbal maupun non verbal merupakan sarana agar terjadi pemahamn yang benar (yang baik dan upaya kadar keilmuan), dari hasil proses berfikir dan berbuat, terhadap gagasan siswa yang ditemukan dan ingin dikembangkan. ${ }^{7}$

\section{b. Langkah-langkah Reading Guide}

Adapun langkah- langkah metode reading guide adalah:

a) Menentukan bacaan yang akan dipelajari.

b) Membuat pertanyaan untuk siswa.

c) Membagikan bahan bacaan kepada siswa.

d) Siswa mempelajari bahan bacaan dengan menggunakam pertanyaan atau kisi-kisi yang ada.

e) Membahas pertanyaan atau kisi-kisi dengan menanyakan jawabannya kepada siswa.

f) Guru mengulas materi di akhir pelajaran. ${ }^{8}$

Metode Reading guide dapat dilakukan apabila materi pelajaran tidak dapat diselesaikan sesuai dengan alokasi waktu yang tersedia. Dan juga dalam metode reading guide guru harus bisa menciptakan suasana kelas yang aktif sehingga peserta didik dapat belajar dengan penuh motivasi.

Agar supaya metode Reading guide dapat dilaksanakan secara efektif (tepat guna), maka diperlukan beberapa langkah kegiatan yang dilakukan oleh guru antara lain :

\section{Persiapan}

Persiapan merupakan salah satu bagian dari program pengajaran yang memuat satu pokok bahasan untuk disajikan dalam proses belajar mengajar.

\footnotetext{
${ }^{7}$ Paul Sj.Suparno, 2002, Reformasi Pendidikan Sebuah Rekomendasi, Yogyakarta, Kanisius, h.43.

${ }^{8}$ Hisyam Zaini, 2004, Strategi Pembelajaran Aktif, Yogyakarta: CTSD, h.8. Jurnal Auladuna | 138
} 


\section{Moh. Sutomo}

Persiapan mengajar ini dapat dipergunakan sebagai bahan acuan guru untuk melaksanakan kegiatan belajar mengajar agar lebih terarah, efektif dan efesien.

Persiapan mengajar disusun mengacu pada GBPP agar terdapat keselarasan antara tujuan, materi, metode dan alat penilaiannya sehingga diperoleh hasil yang optimal yakni menciptakan peserta didik yang baik dari segi kognitif, afektif, dan psikomotorik

Adapun persiapan guru dalam mengajar antar lain :

a) Menyusun rencana pengajaran

Perencanaan merupakan proses penyusunan sesuatu yang akan dilaksanakan untuk mencapai tujuan yang telah ditentukan Perencanaan pembelajaraan yang direncanakan harus sesuai dengan target pendidikan, oleh karena itu untuk mencapai tujuan tersebut tentunya guru harus mempersiapkan perangkat yang harus dilaksanakan dalam merencanakan program.

Menurut Hidayat dalam Mulyasa mengemukakan bahwa perangkat yang harus dipersiapkan dalam perencanaan pembelajaran antara lain :

a. Memahami kurikulum.

b. Menguasai bahan pengajaran.

c. Menyusun program pengajaran.

d. Melaksanakan program pengajaran.

e. Menilai program pengajaran dan hasil proses belajar mengajar yang telah dilaksanakan. ${ }^{9}$

Menyusun rencana pengajaran atau mendesain program pengajaran merupakan salah satu tahapan yang harus dilalui oleh guru melaksanakan tugasnya di depan peserta didiknya dalam mengelola dan mengkondisikan proses belajar mengajar bisa mencapai tujuan yang telah ditetapkan.

Dalam menyusun rencana pengajaran atau desain intruksional harus memperhatikan tujuan dari pembelajaran bagaimana prosedur dan sumber pembelajaran yang tepat untuk dipergunakan serta pengevaluasian hasil belajar yang dapat dicapai.

\footnotetext{
${ }^{9}$ Ibid, h.92.
} 
Harjanto dalam bukunya yang berjudul Perencanaan Pengajaran mengemukakan bahwa suatu perencanaan terdiri atau mengandung 6 pokok pikiran, yaitu:

1) Perencanaan melibatkan proses penetapan kedaan masa depan yang diinginkan.

2) Kedaan masa depan yang diinginkan itu kemudian dibandingkan dengan keadaan sekarang, sehingga dapat dilihat kesenjangan.

3) Untuk menutup kesenjangan tersebut perlu dilakukan usaha-usaha.

4) Usaha yang dilakukan untuk kesenjangan itu dapat beraneka ragam dan merupakan alternatif yang mungkin ditempuh.

5) Pemilihan alternatif yang baik, dalam arti yang mempunyai efektifitas dan efesiensi yang paling tinggi perlu dilakukan.

6) Alternatif yang harus diperinci sehingga dapat menjadi pedoman dalam pengambilan keputusan apabila akan dilaksanakan. ${ }^{10}$

Dengan demikian dapat dimengerti bahwa suatu perencanaan merupakan ketetapan strategi yang akan diterapkan dalam mncapai tujuan yang hal ini masa depan kualitas pendidikan dari peserta didik yang lebih baik dari sekarang serta lebih efektif dan efesien dengan menggunakan metodemetode yang sesuai dengan target yan akan dicapai. Akan tetapi hal ini tidak menutup kemungkinan untuk pengambilan alternatif-alternatif tindakan yang lebih disesuaikan dengan perkembangan kebutuhan dalam proses belajar mengajar.

Dalam menyusun rencana pengajaran atau desain instruksional harus memperhatiakan tujuan dari pembelajaran, bagaimana prosedur dan sumber pembelajaran yang tepat untuk dipergunakan, serta pengevaluasian hasil belajar yang dapat tercapai. ${ }^{11}$

Rencana pengajaran perlu dipersiapkan agar bahn pelajaran yang disajikan kepada peserta didik dalam jam pelajaran tertentu sesuai dengan pedoman instruksional pengajaran. Rencana pengajaran perlu dipersipkan karena mengajar merupakan pekerjaan dan tugas yang kompleks dan sulit,

${ }^{10}$ Op_Cit, h.2-3

${ }^{11}$ Harjanto, 1997, Perencanaan Pengajaran, Jakarta, Rineka Cipta, h. 140. Jurnal Auladuna | 140 
merupakan tugas yang perlu dipertanggung jawabkan serta merupakan tugas mengorganisasi dan mengatur jalannya proses belajar mengajar, oleh karena itu perlu membuat persiapan pengajaran dan dapat dinilai pada akhir kegiatan proses belajar mengajar dilaksanakan.

b) Memahami bahan bacaan.

Dalam pelaksanaan proses belajar mengajar yang mengajar yang lebih efektif, maka seorang guru perlu memahami banyak hal diantaranya seorang guru harus memahami atau senantiasa menilai dirinya sendiri dan kemampuan dirinya sendiri dalam mencapai keberhasilan tujuan pembelajaran yang dilaksanakan, bukan hanya guru yang berhasildalam profesinya. Dalam proses pengajaran bahan pelajaran harus disesuaikan dengan tingkat atau kelas peserta didik.

Setiap guru yang profesional disamping menguasai pengetahuan yang mendalam dalam spesialisasinya juga harus menguasai dengan baik ilmu-ilmu keguruan pada umumnya dan didaktik pada khususnya. Penguasaan pengetahuan ini merupakan syarat yang penting disamping ketrampilanketrampilan lainnya. Oleh sebab itu seorang guru berkewajiban menyampaikan pengetahuan, pengertian, ketrampilan dan lain-lain kepada murid-muridnya.

Dalam memahami bacaan atau kata yang familiar ditelinga adalah penguasaan materi. Setiap guru yang profesional disamping menguasai pengetahuan yang mendalam terhadap spesialisasinya, juga harus me nguasai dengan baik ilmu keguruan pada umumnya dan diktatik pada khususnya. Penguasaan pengetahuan ini merupakan syarat penting disamping ketrampilan lainnya. Oleh sebab itu, penguasaan materi mutlak bagi guru. Untuk hal ini seorang guru harus memiliki kebiasaan membaca dan menelusuri secara mandiri berbagai sumber pustaka dan sumber lain secara maksimal.

Penguasaan materi secara baik menjadi bagian dari kemampuan guru, biasanya merupakan tuntunan pertama dalam profesi keguruan. Namun seberapa banyak materi yang harus dikuasai belum ada tolak ukurnya. Dalam praktek seringkali dapat dirasakan atau diperoleh kesan tentang luas tidaknya penguasaan materi yang dimiliki oleh guru. Namun itupun bukan merupakan 
ukuran yang bersifat pasti sebab masih banyak faktor yang berpengaruh terhadap pengajaran.

Penguasaan materi bagi guru merupakan hal yang sangat menentukan khususnya dalam proses belajar mengajar yang melibatkan guru mata pelajaran. Dalam menguasai materi pelajaran menurut Uzer Usman seorang guru harus memperhatikan hal-hal sebagai berikut:

1) Ruang lingkup materi yang harus dikuasai oleh guru dan siswa.

2) Usaha meningkatkan penguasaan materi.

3) Fungsi pendalaman materi.

4) Langkah pembinaan untuk untuk pendalaman materi bagi guru.

Dalam meningkatkan hasil pembelajaran yang diselenggarakan, maka guru tenaga pengajar mempunyai peranan penting dalam menumbuhakan motivasi siswa dalam belajarnya agar tujuan yang telah dicita-citakan dapat tercapai sesuai harapan.

\section{Penentuan Bacaan}

Pelaksanaan pengajaran selayaknya berpegang pada apa yang tertuang dalam perencanaan. Namun situasi yang dihadapi guru dalam melaksanakan pengajaran mempunyai pengaruh besar terhadap proses belajar mengajar itu sendiri. Oleh sebab itu, guru sepatutnya peka terhadap berbagai situasi yang dihadapi, sehingga dapat menyesuaikan pola tingkah lakunya dalam mengajar dengan mengajar dengan situasi yang dihadapi. ${ }^{12}$

Dalam pelaksanaan disini menjelaskan tentang bagaimana kelanjutan dari perencanaan proses belajar mengajar. Melaksanakan ataupun mengelola program belajar mengajar merupakan tahap pelaksanaan program yang telah dibuat. Dalam pelaksanaan proses belajar mengajar kemampuan yang dituntut adalah keaktifan guru dalam menciptakan dan menumbuhkan kegiatan siswa belajar sesuai dengan rencana yang telah disusun dalam perencanaan. ${ }^{13}$

Mengajar dalam prakteknya merupakan suatu proses penciptaan lingkungan, baik dilakukan guru maupun siswa agar terjadi proses belajar. Menurut

\footnotetext{
${ }^{12}$ Muhammad Ali, 1983, Guru dalam proses belajar mengajar, Bandung: PT. Sinar Baru Algensindo, h.5. ${ }^{13}$ Nana Sudjana, 2002, Dasar-dasar Proses Belajar Mengajar, Bandung, Sinar Baru Algensindo, h. 21. Jurnal Auladuna | 142
} 


\section{Moh. Sutomo}

Joice \& Will, ${ }^{14}$ mengemukakan penciptaan lingkungan meliputi juga penataan nilainilai dan kepercayaan yang akan diupayakan untuk dicapai.

Setiap pelaksanaan proses mengajar menuntut upaya pencapaian suatu tujuan tertentu. Sehingga secara otomatis setiap tujuan menuntut pula suatu model atau metode untuk terciptanya situasi belajar tertentu pula. Oleh sebab itu, kemampuan seorang guru meliputi juga kemampuan memilih suatu model atau metode mengajar yang diperkirakan sesuai untuk proses belajar mengajar.

Sedangkan kegiatan belajar mengajar ditetapkan berdasarkan tujuan dan bahan bacaan atau pelajaran. Dengan demikian terdapat hubungan yang harmonis dan sistematik antara tujuan - bahan atau materi - metode belajar mengajar.

Dalam menyajikan bahan pelajaran kepada peserta didik, pada prinsipnya guru harus berpegang kepada rencana yang telah disusun.

Bahan pelajaran dirumuskan setelah tujuan ditetapkan. Bahan pelajaran harus disusun sedemikian rupa agar dapat menunjang tercapainya tujuan pengajaran.

Bahan pelajaran adalah isi yang diberikan kepada siswa pada saat berlangsungnya proses belajar mengajar. ${ }^{15}$ Bahan pelajaran pada hakikatnya adalah isi dari mata pelajaran atau bidang studi yang diberikan kepada siswa sesuai dengan kurikulum yang digunakannya.

Ada beberapa hal yang perlu diperhatikan dalam menetapkan bahan pengajaran,antara lain :

(a) Bahan bacaan harus sesuai dan menunjang tercapainya tujuan.

(b) Bahan yang ditulis dalam perencanaan mengajar, terbatas pada konsep, atau resume.

(c) Menetapkan bahan pengajaran atau bacaan harus serasi dengan urutan tujuan. ${ }^{16}$

Dalam hal penentuan materi atau bahan atau bacaan, bisa diklasikasikan ke dalam dua bentuk, yakni bacaan pendek dan bacaan panjang. Yang dimaksud dengan Bacaan Panjang ialah teks bacaan berisi satu topik atau satu pokok bahasan.

\footnotetext{
${ }^{14}$ Muhammad Ali, 1983, Guru dalam proses belajar mengajar, Bandung: PT. Sinar Baru Algensindo, h.9.

${ }^{15}$ Nana Sudjana , 2002, Dasar-dasar Proses Belajar Mengajar, Bandung, Sinar Baru Algensindo, h. 67.

${ }^{16}$ Ibid, h.69.
} 
Sedangkan pengertian Bacaan pendek adalah teks yang berisi satu sub pokok bahasan atau sub topik.

Bacaan pendek biasanya diberikan kepada individu, sedangkan bacaan panjang biasa diberikan pada kelompok belajar. Dengan pembagian tugas tersebut maka siswa diharapkan mempunyai pertanyaan dan menyiapkan jawaban. Dengan adanya pembagian bahan pengajaran atau bacaan ini dapat menstimulir kreatifitas siswa yang lebih kondusif dan efektif.

\section{Evaluasi}

Evaluasi atau penilaian merupakan salah satu komponen sistem pengajaran, pengembangan alat evaluasi merupakan bagian integral dalam pengembangan sistem intruksional. Oleh sebab itu fungsi evaluasi adalah dilakukan untuk mengukur sejauh mana tujuan yang telah ditetapkan itu tercpai. ${ }^{17}$

Secara etimologi evaluasi berasal dari kata "to evaluate" berarti menilai yang menurut Mulyasa ialah hasil belajar mencerminkan kemampuan siswa dalam memenuhi suatu tahapan pencapaian pengalaman belajar dalam suatu kompetensi dasar.

Sudah menjadi tugas dan tanggung jawab seorang guru yaitu dalam setiap kegiatan yang dilakukan oleh siswa, maka guru harus tetap memantau, dalam setiap kegiatan ini pun guru dianggap sebagai sosok yang dipandang lebih dari pada murid, harus bisa mengevaluasi dari hasil kerja siswa (membuat pertanyaan serta jawaban).

Evaluasi menurut Worten, Blime R dalam Tayibnapis yaitu; evaluasi telah memegang peranan penting dalam pendidikan antara lain memberi informasi yang dipakai sebagai dasar untuk:

1. Membuat kebijaksanaan dan keputusan.

2. Menilai hasil yang dicapaipara pelajar.

3. Menilai kurikulum.

4. Memberi kepercayaan kepada sekolah.

5. Memonitor dana yang telah diberikan.

${ }^{17}$ Nana Sudjana, 2001, Metode dan Teknik Pembelajaran Partisipatif, Bandung, Falah Production, h.77. Jurnal Auladuna | 144 
6. Memperbaiki materi dan program pendidikan. ${ }^{18}$

Biasanya evaluasi pendidikan selalu dihubungkan dengan hasil belajar, namun saat ini konsep evaluasi mempunyai maksud atau arti yang lebih luas daripada itu.

Sebagai seorang guru, selain mengajar dalam kelas, guru harus mampu menilai prestasi siswa, memahami karakteristik siswanya untuk menciptakan suasana yang lebih bervariasi, memberikan kegiatan belajar yang berbeda antara siswa yang pandai dengan yang kurang. Sehingga nantinya guru akan bisa membuat langkah-langkah intruksional yang tepat dan konstruktif.

Evaluasi juga disebut penilaian seorang guru terhadap proses atau kegiatan belajar mengajar, penilaian tersebut untuk mengetahui sejauhmana tujuan pengajaran yang ditetapkan dapat tercapai disamping itu juga dapat mengetahui hambatan-hambatan yang terjadi dalam proses belajar mengajar.

Jenis evaluasi yang dilaksanakan di madrasah ini adalah sebagai berikut:

(1) Evaluasi formatif, evaluasi ini dilaksanakan pada akhir satuan program pembelajaran.

(2) Evaluasi sumatif, evaluasi ini dilaksanakan pada akhir semester atau akhir tahun.

Sedangkan dalam pelaksanaannya ditempuh melalui teknik tes. Sedangkan bentuk tes yang dipergunakan adalah:

(1) Tes tertulis

(2) Tes lisan

(3) Tes perbuatan atau praktek.

\section{Konsep tentang Pembelajaran}

\section{a. Pengertian Pembelajaran}

${ }^{18}$ Ibrahim, R dan Syaodih Nana, 2003, Perencanaan Pengajaran, Jakarta, Rineka Cipta, h. 2-3. Jurnal Auladuna | 145 
Pembelajaran adalah suatu kombinasi yang tersusun meliputi unsur-unsur manusiawi, material, fasilitas, perlengkapan, dan prosedur, yang saling mempengaruhi mencapai tujuan pembelajaran. ${ }^{19}$

Manusia terlibat dalam sistem pengajaran terdiri dari siswa, guru, dan tenaga lainnya, misalnya tenaga laboratorium. Material, meliputi: buku-buku, papan tulis, dan kapur, fotografi, slide, film, audio, dan video tape. Fasilitas dan perlengkapan, terdiri dari ruangan kelas, perlengkapan audio visual, juga komputer. Prosedur, meliputi jadwal dan metode penyampaian informasi, praktik, belajar, ujian dan sebagainya.

\section{1) Teori-teori Pembelajaran}

Berdasarkan teori belajar, ada 5 pengertian pengajaran:

a) Pengajaran ialah upaya menyamkan pengetahuan kepada peserta didik disekolah.

b) Pengajaran adalah mewariskan kebudayaan kepada generasi muda melalui lembaga pendidikan sekolah.

c) Pembelajaran adalah upaya mengorganisasi lingkungan untuk menciptakan kondisi belajar bagi peserta didik:

d) Pembelajaran adalah upaya mempersiapkan peserta didik untuk menjadi warga masyarakat yang baik.

e) Pembelajaran adalah suatu proses membantu peserta didik menghadapi kehidupan masyarakat sehari-hari. ${ }^{20}$

\section{2) Ciri-ciri Pembelajaran}

Strategi pembelajaran berpusat pada peserta didik adalah kegiatan pembelajaran yang memberikan kesempatan seluas-luasnya kepada peserta didik untuk terlibat dalam perencanaan, pelaksanaan, dan penilaian pembelajaran.

Strategi pembelajaran yang berpusat pada paserta didik memiliki beberapa ciri. Ciri-ciri tersebut adalah bahwa pembelajaran menitik beratkan pada keaktifan peserta didik, kegiatan belajar dilakukan secara kritis dan analitik, motivasi belajar relatif tinggi, pendidik (guru) hanya berperan sebagai pembantu (fasilitator) peserta didik dalam proses belajar mengajar. ${ }^{21}$

\footnotetext{
${ }^{19}$ Oemar Hamalik , 2001, Kurikulum Dan Pembelajaran, Jakarta: Bumi Aksara, h. 57

${ }^{20}$ Ibid, h.70.

${ }^{21}$ Nana Sudjana, 2001, Metode dan Teknik Pembelajaran Partisipatif, Bandung, Falah Production, h.37-38. Jurnal Auladuna | 146
} 


\section{Moh. Sutomo}

Sedangkan menurut Oemar Hamalik ada tiga ciri yang terkandung dalam sistem pembelajaran, ialah:

a) Rencana, ialah penataan ketenagaan, material, dan prosedur, yang merupakan unsu-unsur sistem pembelajaran, dalam suatu rencana khusus.

b) Saling ketergantungan (interdependence), antara unsur sistem pembelajaran yang serasi dalam suatu keseluruhan.

c) Tujuan, sistem pembelajaran mempunyai tujuan tertentu yang hendak dicapai. ${ }^{22}$

\section{3) Unsur-unsur Pembelajaran}

Unsur minimal dalam sistem pembelajaran adalah siswa, tujuan, dan prosedur., sedangkan fungsi guru dapat dialihkan kepada media pengganti. Unsur dinamis pembelajaran pada diri guru terdiri dari motivasi membelajarkan siswa dan kondisi guru siap membelajarkan siswa. Unsur pembelajaran konkruen dengan unsur belajar meliputi: motivasi belajar, sumber bahan belajar, alat bantu belajar, suasana belajar, subjek yang belajar.

\section{PENUTUP}

Dalam proses pembelajaran guru masih banyak menggunakan metode konvensional, dimana metode ini menuntut peserta didik untuk mengiyakan apa yang telah dikatakan oleh guru. Guru tidak membiasakan peserta didik untuk menjadi lebih aktif dari pada guru, padahal pada era sekarang ini tuntutan zaman sangat membutuhkan output yang handal dalam segala hal. Permasalahan yang seringkali dijumpai dalam pelajaran, khususnya pengajaran agama Islam adalah bagaimana cara menyajikan materi kepada siswa secara baik dan efesien. Disamping itu masalah lainnya adalah kurang perhatiannya guru agama Islam dalam memberi variasi penggunaan metode mengajar dalam proses belajar mengajar dan meningkatkan mutu pengajaran yang baik. Yang patut dipertanyakan adalah adakah metode pembelajaran yang paling sesuai agar terjadi proses belajar aktif? Tidak ada satupun metode pembelajaran yang paling baik bila dibandingkan dengan lainnya, masing-masing memiliki keunggulan dan kelemahannya. Setiap metode pembelajaran yang membantu peserta didik melakukan kegiatan dan akhirnya dan mengkonstruksi pengetahuan yang mereka pelajari. Begitupun juga dengan metode reading guide peserta didik diharapkan dapat menemukan sebuah pertanyaan, memiliki

\footnotetext{
${ }^{22}$ Ibid, h. 65-66.
} 
sebuah gagasan dan sebagainya. Hal ini menstimulasi peserta didik dalam menemukan dengan penekanan pada berpikir ilmiah. Dalam penerapan metode ini peserta didik dilatih untuk terbiasa membaca, membuat hipotesis, memunculkan prediksi, memecahkan persoalan, mencari jawaban sendiri, berdialog, dan membuat pertanyaan. Dari uraian di atas sangat jelas bahwa melakukan proses pembelajaran dengan metode ceramah, dimana guru mendominasi pembicaraan sementara peserta didik terpaksa atau dipaksa untuk hanya duduk, mendengar, dan mencatat sangat tidak dianjurkan. Metode ceramah harus dikurangi bahkan ditinggalkan. 


\section{Moh. Sutomo}

\section{DAFTAR PUSTAKA}

Ahmadi Abu, 1997, Strategi Belajar Mengajar untuk Fakultas Tarbiyah Komponen MKDK, Bandung:

Pustaka Setia

Ahmadi, 1997, Strategi Belajar Mengajar, Bandung: Pustaka Setia

Ali, Muhammad, 1983, Guru dalam proses belajar mengajar, Bandung: PT. Sinar Baru Algensindo

Broto, A.S, 1980, Pengajaran Bahasa Indonesia Sebagai Bahasa Kedua di Sekolah Dasar Berdasarkan Pendekatan Linguistik. Kontrastif, Jakarta: Bulan Bintang

Building reading profieciency at the secondary level: A guide to resources, reading guides strategy, http://www.sedl.org/cgi-bin/mysql/ buildingreading.cgi?showrecord, diakses 28 Juni 2006

Departemen Agama RI, 1989, Al-Qur'an dan Terjemahannya, Semarang, CV. Thoha Putra

Departemen Agama RI, 2003, Standar Penilaian di Kelas, Jakarta.

Departemen Agama RI, 2004, Standar Kompetensi guru Pendidikan Agama Islam pada Sekolah Umum dan Madrasah, Jakarta

Departemen Agama RI, 2004, Strategi Pengembangan Ilmu Pengetahuan dan Teknologi di Madrasah, Jakarta

Departemen Pendidikan dan Kebudayaan, 1991, Kamus Besar Bahasa Indonesia, Jakarta, Balai Pustaka

Hamalik, Oemar, 2002, Psikologi Belajar Mengajar, Bandung: Sinar Baru Algensindo

Hamalik, Oemar, 2001, Kurikulum Dan Pembelajaran, Jakarta: Bumi Aksara.

Harjanto, 1997, Perencanaan Pengajaran, Jakarta, Rineka Cipta

Hasibuan, Moedjiono, 1999, Proses Belajar Mengajar, Bandung, Rosdakarya

Horney, A S, 1974, Oxford Advanced Learner's Dictionary Of Current English, Oxford Univercity Press

Ibrahim, R dan Syaodih Nana, 2003, Perencanaan Pengajaran, Jakarta, Rineka Cipta

Ihsan, Hamadi dan Fuad, 2001, Filsafat Pendidikan Islam, Bandung, Pustaka Setia

Majid Abdul, 2005, Pendidikan Agama Islam Berbasis Kompetensi”, PT Remaja Rosdakarya”, Bandung

Majid, Abdul \& Andayani, 2005, Pendidikan Agama Islam Berbasis Kompetensi, Bandung: Remaja Rosdakarya

Mardalis, 2003, Metode Penelitian Suatu Pendekatan Proposal, Jakarta: Bumi Aksara

Muhaimin, 2002, Paradigma Pendidikan Islam Upaya Mengefektifkan Pendidikan Agama Islam di Sekolah, Bandung, Rosdakarya

Namsa, Yunus, 2000, Metodologi Pengajaran Agama Islam, Jakarta: Pustaka Firdaus

Nana Sudjana, 1988, Dasar-dasar Proses Belajar Mengajar, Bandung: Sinar Baru Algensindo Offset.

Paraba, Hadirja, 2000, Wawasan Tugas Tenaga Guru dan Pembina Pendidikan Agama Islam, Jakarta: Friska Agung Insani

Paul Sarjono, SJ, 2002, Reformasi Pendidikean sebuah Rekomendasi, Yogjakarta: Kanisius

Sastrawijaya, Tresna, 1991, Pengembangan Program Pengajaran, Jakarta: Rineka Cipta

Slameto, 1995, Belajar dan Faktor-faktor yang Mempengarubinya, Jakarta: Rineka Cipta

Suparno, Paul, Sj, 2002, Reformasi Pendidikan Sebuah Rekomendasi, Yogyakarta, Kanisius

Undang-Undang Republik Indonesia No. 20 Tahun 2003, Tentang Sistem Pendidikan Nasional, 2003, Bandung: Citra Umbara

Usman, Uzer, 2002, Menjadi Guru Proesional, Bandung, Rosdakarya

Zaini, Hisyam, 2004, Strategi Pembelajaran Aktif, Yogyakarta: CTSD

Jurnal Auladuna | 149 